\title{
Degenerative progressive hereditary mieloencefalopathy (Weaver Syndrome) in Gir calves
}

\author{
Mieloencefalopatia degenerativa progressiva hereditária (Síndrome da Oscilação) \\ em bezerros Gir
}

\section{Pedro Carlos Lucas de Oliveira ${ }^{I^{*}}$ Humberto Eustáquio Coelho $^{\mathrm{I}}$ Alessandra Aparecida de Medeiros ${ }^{\mathrm{I}}$ Susana Elisa Rieck ${ }^{\mathrm{I}}$ Juliana Meirelles de Souza' Rodrigo Rodrigues Alvarenga ${ }^{\mathrm{I}}$}

\section{ABSTRACT}

Degenerative progressive hereditary mieloencefalopathy is a disease described in young Brown Swiss cattle. In these animals the disease occurs in calves between six months and two years old showing mainly neurological signs. Two Zebu Gir calves were examined at the Veterinary Hospital of Uberaba, both with balance deficits. The neurological examination has shown that they were mentally alert, with appropriate conscience, head tremor, normal sensitive reflexes, normal sensitivity for superficial and deep pain, motor deficit of the pelvic limbs with severe ataxia. The calves were sacrificed. Based on the clinical case and necroscopic and histopathological findings, it could be suggested that the neuropathy, which affected both animals described above, is very similar to the degenerative progressive hereditary mieloencefalopathy observed in Brown Swiss calves.

Key words: mieloencefalopathy, degenerative, bovine, Gir.

\section{RESUMO}

A mieloencefalopatia degenerativa progressiva hereditária é uma doença descrita em bovinos Pardo Suíço. Nesses animais, a doença ocorre em bezerros de seis meses a dois anos de idade, e os principais sinais clínicos são nervosos. Dois bezerros Gir foram atendidos no Hospital Veterinário de Uberaba, ambos com dificuldades de equilíbrio motor. $O$ exame clínico revelou estado mental alerta, consciência apropriada, tremores de cabeça, reflexos sensitivos normais, sensibilidade à dor profunda e superficial normal, déficit motor dos membros posteriores com intensa incoordenação. Os bezerros foram sacrificados. Baseado no quadro clínico e nos achados necroscópicos e histopatológicos, pode-se sugerir que a neuropatia que acometeu os dois animais descritos em muito se assemelha à mieloencefalopatia degenerativa progressiva hereditária, observada em bovinos da raça Pardo Suíço.

Palavras-chave: mieloencefalopatia, degenerativa, bovino, Gir.

\section{INTRODUCTION}

The degenerative progressive hereditary mieloencefalopathy, also known as "weaver syndrome" (RADOSTITS et al., 2002b), is a hereditary defect that is described as occurring in Brown Swiss cattle (GEORGES et al., 1993; RADOSTITS et al., 2002b). Males are more commonly affected than females. It is expected that, for 100,000 Brown Swiss bovines registered in the United States, 563 cases of the disease occur (STUART \& LEIPOLD, 1985). In these animals, the disease occurs in cattle between six months and two years old and, occasionally, later. The main clinical signs are ataxia, progressive weakness of the pelvic limbs, difficulties to stand up, proprioceptive deficit and oscillatory hypermetric walking (GEORGES et al., 1993; RADOSTITS et al., 2002b). The mental state is always alert and all the reflexes are always present and normal. The case progresses to sternal recumbency after 18 to 36 months of evolution, although the appetite and thirst remain normal (LEIPOLD et al., 1973; STUART \& LEIPOLD, 1983). Failure in the spermatogenesis and ovarian functions were also described (STUART \& LEIPOLD, 1983). Mostly, death does not come spontaneously by the injuries of the disease, and after months of evolution, the euthanasia is indicated (RADOSTITS et al., 2002b). Some animals may die due to the long time of recumbency or rumenal meteorism (GEORGES et al., 1993). At the necropsy, axonal degeneration with formation of spheroids and vacuolation in the cerebellar white matter and in the spinal cord, mainly in the thoracic segment, were

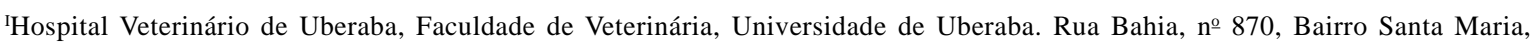
38050-130, Uberaba, MG, Brasil. E-mail: pedrolucaso@uol.com.br. *Autor para correspondência. 
observed (AITCHISON et al., 1985; STUART \& LEIPOLD, 1985). An ultrastructural study revealed reduction of synaptic junction densities in the affected animals, indicating lesions in neurotransmitters liberation, dysfunction of the terminal synaptic plates, or lost of the motor cortex specific cells. There is no muscle alteration, although neurogenic atrophy may occur (AITCHISON et al., 1985). The disease is chromosomal, and it is believed that it is related to the high milk production (GEORGE, 2002), and may be identified by the examination of the chromosomes (GEORGES et al., 1993). A similar disease has been described in the Murray Grey cattle (EDWARDS et al., 1988).

\section{MATERIAL AND METHODS}

Two Zebu Gir calves, one male and one female, sons of the same bull but of different cows, about two months old, white and yellow skin, were examined at the Hospital of the Veterinary College, from the University of Uberaba - UNIUBE - Uberaba, MG / Brazil, both with balance deficits and difficulties to stand up. The clinical examination followed what is recommended by RADOSTITS et al. (2002a). The nervous system was examined by evaluation of the mental attitude, gait, head and limbs posture, cranial nerves, sensitivity for superficial and deep pain and evaluation of the spinal reflexes, as recommended by BORGES (2004). The hematological parameters and cerebrospinal fluid were analyzed and evaluated as the techniques recommended for the bovine species by JAIN (1993) and FEITOSA (2004b), respectively.

\section{RESULTS}

The clinical history revealed that every year one or two calves were born normal and, some days later, they got ill showing loss of balance and difficulties to move the pelvic limbs, falls and evolution to sternal recumbency. The animals were always alert and had normal appetite and thirst. Along the years, at the farm, always after a few months all the sick animals were sacrificed.

The calves, presented for examination, had so far twenty days of disease evolution, with identical clinical signs to those that were born in the past years. The first signs were balance loss of the pelvic limbs, hypermetric walk, head tremor, tendency to lay down in sternal recumbency and slow and progressive evolution. They were treated by their owner with unknown amounts of vitamins and penicillin.

At general clinical examinations, the animals were in good state of health, docile and were in sternal recumbency. The rectal temperature, heart and respiratory rates were within normal values, according to FEITOSA (2004a).

The neurological examination has shown that they were mentally alert, had appropriate conscience, head tremor, normal reflexes, normal sensitivity for superficial and deep pain, sensitive motor deficit of the pelvic limbs, with a severe ataxia which led to falls, and turned the animals unable to stand up for a period of time over a few seconds (Figure 1).

The standard hematological (JAIN, 1993) and cerebrospinal fluid (FEITOSA, 2004b) parameters had normal values for the bovine species and are shown on tables 1 and 2 .

The male calf was designated to the euthanasia and necroscopic examination. The female calf was kept under observation for 15 days. During this time, the clinical picture has constantly deteriorated, and the sacrifice was also indicated.

At the necropsy, done by the technique described by JONES \& GLEISER (1954) and BAKER \& ALVARADO (1969), a large amount of cerebrospinal fluid was seen and the cerebellum matter was softer than usual. The histological examination revealed vacuolation of the white matter of the cerebellum and axonal degeneration (Figure 2). No other lesion was found.

\section{DISCUSSION}

The literature does not describe neurological alterations, in Gir cattle, or in any other Zebu cattle, compatible to those observed in these calves, although, many neuropathies are described in taurine breed calves, mostly, an abiotrophy coming from an autossomic recessive disease (GEORGE, 2002).

Some nervous system hereditary defects described in taurine breed calves could be considered in the differential diagnosis for the calves in this report, because they lead to clinical signs similar to the degenerative progressive hereditary mieloencefalopathy. These defects are: mannosidosis, rejected by causing deformity at the skull and face (JOLLY, 1993); gangliosidosis, but the signs of this disease should include absence of response to external stimulus and slow mastication and deglutition (JOLLY, 1993); cerebellar abiotrophy, but the histological 


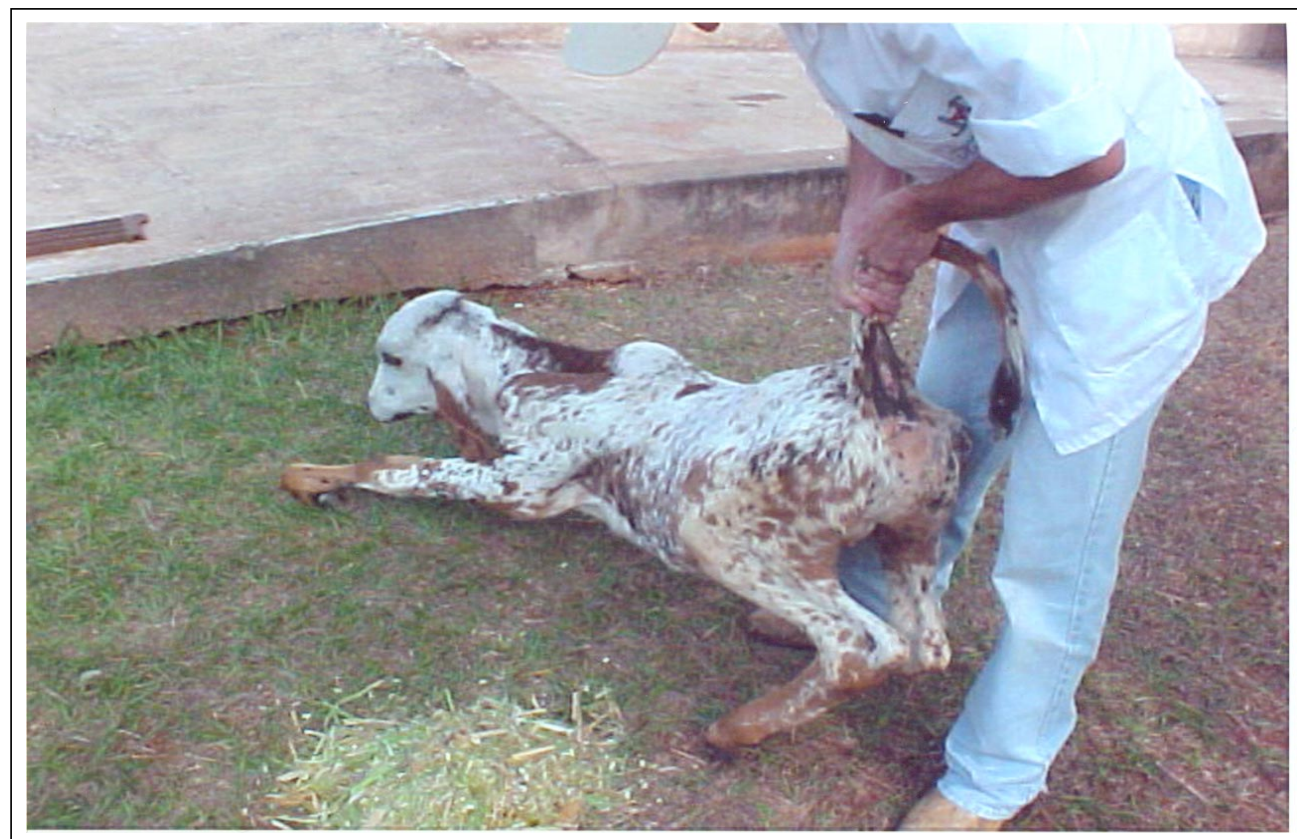

Figure 1 - A Gir calf, with a weaver syndrome like condition, trying unsuccessfully to stand up with help.

findings include loss of the Purkinge cells (DE LAHUNTA, 1990); hereditary neurodegeneration, but it is a recessive mutation linked to the sex, occurring only on males (GEORGE, 2002); calves's hereditary ataxia, but histological examination reveals aplasia of the cerebellum neurons (GEORGE, 2002).
On the other hand, LEIPOLD et al. (1973), STUART \& LEIPOLD (1983), GEORGES et al. (1993) and RADOSTITS et al. (2002b) reported Brown Swiss calves showing clinical signs very similar to the Gir calves in this report (Figure 1). And, at the Gir calves's necropsy, vacuolation of the white matter of the

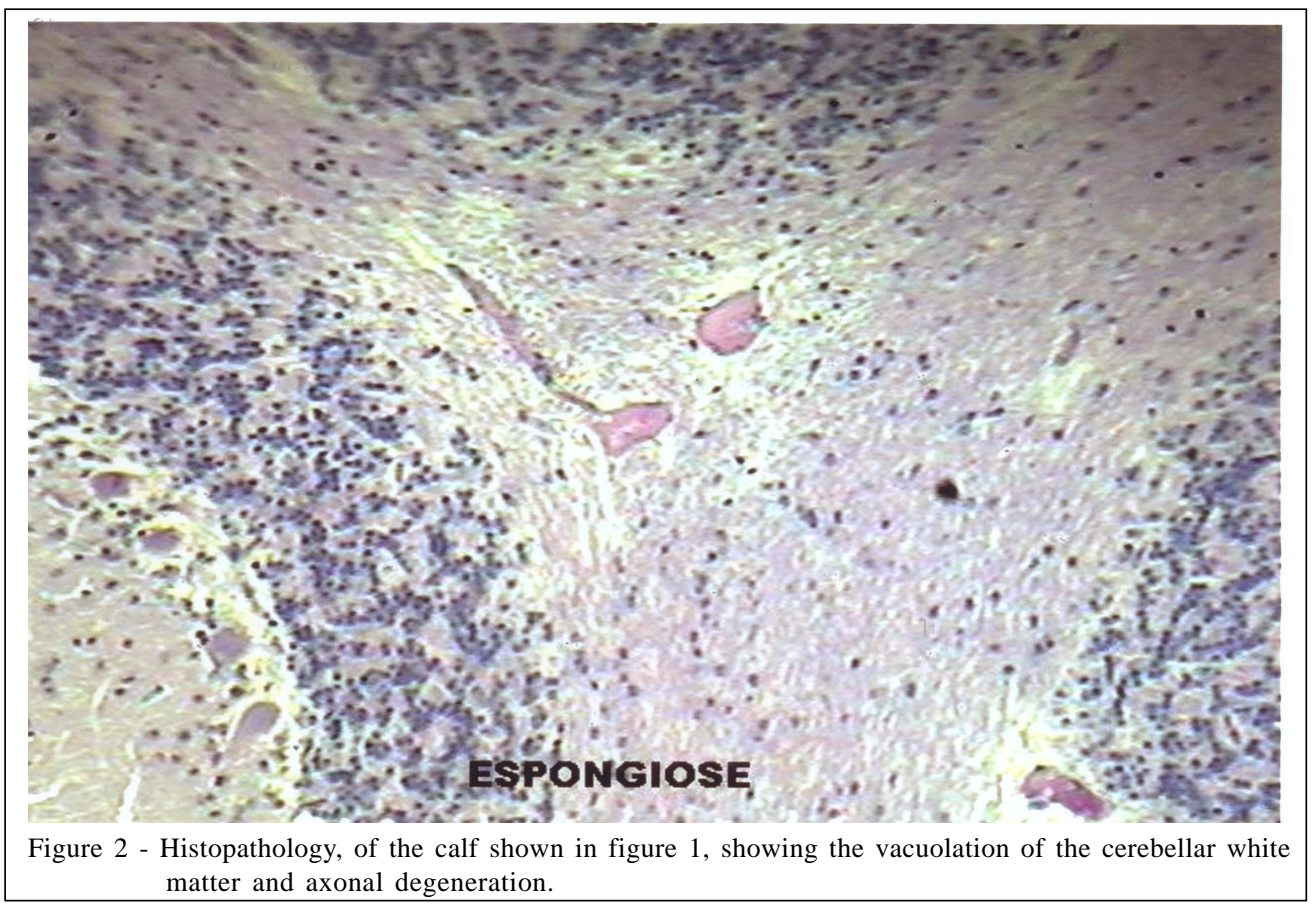

Ciência Rural, v.38, n.1, jan-fev, 2008. 
Table 1 - Hematological parameters observed on two Gir calves with a weaver syndrome like condition.

\begin{tabular}{llll}
\hline Parameter & Male calf & Female calf & Normal value \\
\hline Erythrocytes & $7.44 \times 10^{3}$ & $10.00 \times 10^{3}$ & $5-10 \times 10^{3} / \mathrm{mm}^{3}$ \\
Hemoglobin & 8.0 & 9.80 & $8-15 \mathrm{~g} \%$ \\
Globular volume & 29 & 31 & $24-46 \%$ \\
Plasmatic protein & 7.0 & 7.5 & $7-8.5 \mathrm{~g} / \mathrm{dL}$ \\
Fibrinogen & 500 & 300 & $300-700 \mathrm{mg} / \mathrm{dL}$ \\
Platelets & $189 \times 10^{3}$ & $211 \times 10^{3}$ & $100-800 \times 10^{3} / \mathrm{mm}^{3}$ \\
Leukocytes & 11,600 & 10,700 & $4,000-12,000 / \mathrm{mm}^{3}$ \\
Neutrophils & 3,308 & 3,531 & $600-4,000 / \mathrm{mm}^{3}$ \\
Lymphocytes & 7,794 & 6,955 & $2,500-7,500 / \mathrm{mm}^{3}$ \\
Monocytes & 498 & 214 & $25-840 / \mathrm{mm}^{3}$ \\
\hline
\end{tabular}

OBS: other kinds of blood cells not found in this table were never identified in the exams.

cerebellum and axonal degeneration were found (Figure 2), exactly the same described by AITCHISON et al. (1985) and STUART \& LEIPOLD (1985), which was axonal degeneration with formation of spheroids and vacuolation in the cerebellar white matter and in the spinal cord.

Therefore, despite the degenerative progressive hereditary mieloencefalopathy is a very well known disease in Brown Swiss calves, the similarity of the clinical and pathological signs allows to consider that this disease may also occur on Gir calves.

\section{CONCLUSION}

Based on the clinical and pathological findings, also macro and microscopic, it can be suggested that the neuropathy described is very similar to the degenerative progressive hereditary mieloencefalopathy, observed on Brown Swiss calves.

Table 2 - Cerebrospinal fluid parameters observed on two Gir calves with a weaver syndrome like condition.

\begin{tabular}{llll}
\hline Parameter & Male calf & Female calf & Normal value \\
\hline Volume & 2.0 & 4.0 & variable \\
Color & uncolored & uncolored & uncolored \\
Odor & Sui generis & Sui generis & Sui generis \\
Aspect & Limpid & Limpid & Limpid \\
Density & 1005 & 1006 & $1006-1012$ \\
Protein & 17 & 22 & $10-40 \mathrm{mg} / \mathrm{dL}$ \\
Blood presence & absent & absent & absent \\
pH & 8.0 & 8.0 & $7-9$ \\
Glucose & 65 & 84 & $50-90 \mathrm{mg} / \mathrm{dL}$ \\
Pandhy & negative & negative & negative \\
Blood cells & absent & absent & absent \\
\hline
\end{tabular}

\section{REFERENCES}

AITCHISON, C.S. et al. Ultrastructural alterations of motor cortex synaptic junctions in Brown Swiss cattle with weaver syndrome. Am J Vet Res, v.46, p.1733-1736, 1985.

BAKER, R.D.; ALVARADO, D.M. Técnicas de necropsia. México: Interamericana, 1969. 109p.

BORGES, A.S. Semiologia do sistema nervoso de grandes animais. In: FEITOSA, F.L.F. Semiologia veterinária - A arte do diagnóstico. São Paulo: Roca, 2004. Cap.10, p.506526.

DE LAHUnTA, A. Abiotrophy in animals, a review. Am J Vet Res, v.54, p.65-76, 1990.

EDWARDS, J.R. et al. Inherited spinal myelinopathy in Murray Gray cattle. Aust Vet J, v.65, p.108-109, 1988.

FEITOSA, F.L.F. Semiologia veterinária - A arte do diagnóstico. São Paulo: Roca, 2004a. 807p.

FEITOSA, M.M. Exames complementares. In: FEITOSA, F.L.F. Semiologia veterinária - A arte do diagnóstico. São Paulo: Roca: 2004b. Cap. 10, p.527-546.

GEORGE, L.W. Moléstias do sistema nervoso. In: SMITH, B.P. Tratado de medicina interna de grandes animais. São Paulo: Manole, 2002. Cap.33, p.901-1040.

GEORGES, M. et al. Microsatellite mapping of the gene weaver disease in cattle will allow the study of an associated quantitative trait locus. Proc Natl Acad Sci, v.90, p.1058-1062, 1993.

JAIN, N.C. Essentials of veterinary hematology. 5.ed. Philadelphia: Lea \& Febiger, 1993. 417p.

JOLLY, R.D. Lysosomal storage diseases in livestock. Vet Clin North Am: Food Animal Pract, v.9, p.41-53, 1993.

JONES, T.C.; GLEISER, C.A. Veterinary necropsy procedures. Philadelphia: Leppincott, 1954. 136p. 
LEIPOLD, H.W. et al. Weaver syndrome in Brown Swiss cattle: clinical signs and pathology. Vet Med Small Anim Clin, v.68, p.645-647, 1973.

RADOSTITS, O.M. Exame clínico de bovinos adultos e bezerros. In__. RADOSTITS, O.M. et al. Exame clínico e diagnóstico em veterinária. Rio de Janeiro: Guanabara Koogan, 2002a. p.118-139.

RADOSTITS, O.M. et al. Doenças causadas pela herança de caracteres indesejáveis. In: RADOSTITS, O.M. Clínica veterinária - Um tratado de de doenças de bovinos, ovinos, suínos, caprinos e eqüinos. Rio de Janeiro: Roca, 2002b. Cap.30, p.1561-1593.

STUART, L.D.; LEIPOLD, H.W. Bovine progressive degenerative myeloencephalopathy "weaver" of Brown Swiss cattle II. Clinical and laboratory findings. Bovine Pract, v.18, p.133-146, 1983.

STUART, L.D.; LEIPOLD, H.W. Lesions in bovine progressive degenerative myeloencephalopathy "weaver” of Brown Swiss cattle I. Vet Pathol, v.22, p.13-23, 1985. 